Sir Richard Douglas Powell, who although suffering from an attack of influenza came willingly to court, was no less valuable. If such sympathy can be displayed, ought not many to carry out the good advice of THE LANCET and join others who have been, and are, doing their best for one who did his best for his patient?

I leave the matter in the hands of my brethren, thanking the medical profession for what it has already done, and especially the medical press, ever jealous of maintaining its reputation of being a noble and generous profession.

$$
\text { I am, Sirs, yours faithfully, }
$$

RICHARD PARAMORE.

2, Gordon-square, W.C., June 3rd, 1902.

PS. - I inclose a list of additional subscriptions. ${ }^{1}$ Postal orders and cheques should be made payable to the Law Fund and crossed London and County Bank, Holborn, W.C.

\section{THE SIMULATION OF ABDOMINAL THORACIC INFLAMMATION.}

BY To the Editors of THE LANCET.

SIRS, - The reference to the paper of Mr. H. L. Barnard and Dr. M. H. Richardson on "The Simulation of Abdominal by Thoracic Inflammation" in THE LANCET of May 17th, p. 1414, reminds me of a case under my care some few years ago. I was called late in the evening to a man said to be suffering from acute abdominal pain. I was told by the wife that the pain had come on shortly after a light meal partaken of by her husband on returning from work, and both she and the patient had confidently diagnosed the case as one of poisoning by the margarine eaten at this meal. On examination I found the abdomen somewhat rigid and apparently markedly tender without any specially tender spots. Vomiting had occurred without any great relief. The temperature was normal and the pulse and respiration, though both increased, were not. I think, very significant of the condition afterwards diagnosed. I do not now remember exactly what increase they showed or what was the ratio, but I remember I proceeded to examine the chest rather to satisfy myself that I was not missing anything than because I expected to find the main cause of trouble there. The patient, who was evidently suffering acute pain-all, or nearly all, referred to the abdomen-considered this chest examination a work of supererogation which he was irritably inclined to resent. I was very glad, however, that I made it, as I found fairly well-marked signs of pneumothorax on the right side, which helped to clear up what promised to be a difficult and misleading case. This patient, I may add, recovered after a somewhat protracted illness, and I have no reason to suppose that there was any abdominal disease to account for the severe pain referred to that region. This condition of "referred pain" is a possibility which must be constantly borne in mind if one would avoid mistakes. Perhaps the most familiar instance of it is that of pain in the knee-joint due to hip-joint disease, but many other examples could be given which are frequently met with by every practitioner.

May.20th, 1902. I am, Sirs, yours faithfully,

R. WHITTINGTON.

\section{SOUTH AFRICAN CIVIL SURGEONS' DINNER.}

To the Editors of THE LANCET.

SIRs, - We shall be much obliged if you will allow us the use of your columns to request all civilian medical men who have served during the recent war in South Africa to do their best to be present at the above dinner at the Hotel Cecil, next Monday, at 7.30 P. M. Sir F. Treves will be in the chair, and the Director-General and Deputy Director-General of the Army Medical Service will be the principal guests. There will be two toasts, those of "The King" and of "The Imperial Forces," so as to leave ample time for the main object of the evening-the renewal of South African friendships and memories. Tickets, price $10 s$. $6 d$. each, may be purchased at the door, but we shall be glad to be informed beforehand of intending diners. Medals and orders may be worn.-We are, Sirs, yours faithfully,

$\left.\begin{array}{l}\text { Francis E. FremantLe, } \\ \text { C. GoRdon Watsos, }\end{array}\right\} \begin{gathered}\text { Honorary } \\ \text { Secretaries. }\end{gathered}$

The College, St. Bartholomew's Hospital, E.C., June 4th, 1902.
THE ROYAL NAVY MEDTCAL SERVICE AND THE ROYAL ARMY MEDICAL CORPS: A COMPARATIVE VIEW.

\section{To the Editors of THE LANCET.}

SIRs, - I have read with much interest your leading article and the new regulations for the Naval Medical Service, both published in THE LANCET of April 26th. As the parent of a prospective candidate for one of the services just about qualifying, the following points of difference between the new Army Warrant for the Royal Army Medical Corps and the new naval regulations struck me as being worthy of careful consideration.

1. Article 349, new Army Warrant, seconds newly-entered officers while holding appointment of house surgeon at a civil hospital and guarantees them the time so spent shall count towards promotion, pension, \&c. The new naval regulations say, if a surgeon has held the appointment of house surgeon before entry he may receive earlier promotion to staffsurgeon.

2. Article 352, Army, gives officers the opportunity of gaining from three to 18 months' earlier promotion on passing their promotion examination with distinction. Navy: No such provision.

3. Articles 356 and 366, Army: Brevet promotion and brevet pay in addition to ordinary pay for a captain in the Royal Army Medical Corps. Navy: No similar provision.

4. Article 368, Army: Charge-pay for officers of whatever rank in charge of beds according to numbers. Navy: Charge-pay for inspector-generals only. Three out of a total of some 500 of all ranks.

5. Officers of the Royal Army Medical Corps may be granted full-pay sick leave up to one year with possibility of extension. Navy : Limited to three months, after which half-pay.

6. Officers of the Royal Army Medical Corps qualifying as specialists to receive $2 s .6 d$. a day in addition to ordinary pay. Navy: No such provision.

7. Staff surgeons employed in London to receive hospital allowances of $£ 53$ in addition to lodging allowances of $£ 50$, total $£ 103$ per annum. Major in the Royal Army Medical Corps of equivalent rank is to receive allowances totalling to $£ 160$ per annum.

Does the Admiralty really think that with all these substantial differences in favour of the Royal Army Medical Corps candidates of ability will ever be likely to enter the navy as surgeons, so long as they can be received into the Royal Army Medical Corps? I notice that the Admiralty is now advertising 30 commissions as surgeons for competition in June. Let it equate the conditions of its service to those of the Royal Army Medical Corps if it really desires candidates to respond.

May 17th, 1902. I am, Sirs, yours faithfully, PARENT.

\section{NOTES FROM INDIA.}

\section{(From our Special Correspondent.)}

The Plague Epidemic.-Disgraceful State of the City of Ahmedabad.-The Religious Census of India.-The Prevention of Tuberculous Disease.

THE plague epidemic throughout India continues to show signs of declining. The total mortality for this week is 15,748 against 17,302 for the previous seven days. For the corresponding week of last year the deaths from plague amounted to only 3208. The figures for this week are smaller every where but the epidemic may be said to be raging fiercely at Karachi, Bombay, and Calcutta, and more especially throughout the affected districts of the Punjab. The figures are: Bombay city, 486 deaths ; Bombay districts, 930 ; Karachi city, 106 ; Madras Presidency, 11 ; Calcutta, 441 ; Bengal districts, 473 ; United Provinces, 718 ; the Punjab, 12,334; Central Provinces, 98: Hyderabad State. 28 ; Kashmir, 108 ; and Berar, 18.

I have frequently pointed out the incompetency of certain municipalities in India for the sanitary administration of their towns. The city of Ahmedabad has become so bad that the Commissioner of the district has bad to threaten to move the Government to interfere. The mortality has been increasing and is now 77 per 1000 without any epidemic to account for it. The city is overcrowded and dirty, and the 
paths and roadways are very badly kept up. Accumulations of refuse abound, there is a want of surface drainage, the roads are very irregularly watered, and a great waste of pipe-water goes on. There is an open violation of by-laws regarding dangerous and offensive trades. Encroachments are permitted on the public roads, insanitary dwellings are very numerous, and nuisances abound. The registration of births and deaths is very defective and the taxes are remissly collected. This is a sufficiently strong indictment against the corporation and it is to be hoped that Government will take the administration of the city out of its hands.

It will probably interest your readers to hear the result of the census so far as the numerical distribution of the chief religions in India is concerned : Hindus, 207,075,277; Sikhs, 2,195,268 ; Jains, 1,334,148 ; Buddhists, 9,476,450 ; Parsees, 94,190 ; Mahomedans, 62,458,061 ; Christians, 2,923,241 Jews, 18,228.

The Bombay Municipality some time ago appointed a committee to frame measures for the prevention of tuberculous disease. The following is the report of this committee :-

The committee have carefully studied the resolutions passed at the general meeting of the British Congress on Tuberculosis on July 27th conditions and to the habits and prejudices of the varied population of this city. With the conclusions of the Congress, as embodied in their resolutions, this committee are in full accord, and although it would not be possible in this country to give effect to all their recommendations, yet it seems to this committee that it is absolutely neces sary to do samething in the direction indicated by them to combat so fell a disease as phthisis which is year after year so increasingly conspicuous in the mortality returns of the city. In consultation with the health officer the committee have framed the following suggestions for the prevention of the disease, which they think are of a practical nature and not unsuited to the circumstances prevailing in the city :-

nary notification by medical men to the

2. Filities tosis coming to their knowledge. 2. Facilities to be given for a bacteriological examination of sputam bacilli medical ment.

bacilli are present.

3. Instructions to be given how to disinfect a room in which a case tuberculosis has occurred and died.

4. Instructions to be given how to disinfect sputum and to prevent the bacilli spreading the disease.

5. Disinfection and lime-washing of every infected house at municipal expense, where necessary in the opinion of the health officer, and systematic lime-washing of every common lodging-house twice a yea at owner's expense.

6. Printed instructions in English and the vernaculars to the people and instructions by male and female visitors as to the precautions necessary to prevent the spread of disease and notices posted as to spitting.

7. Prevention of overcrowding in houses, factories, and workshops.

8. Ventilation of houses, printing-offices, and workshops, and removal of dust from wool- and cotton-cleaning godowns and all trade processes causing pollution of air liable to affect the lungs and predispose to infection.

9. Inspection of milk-and meat-supplies and analysis of milk.

The committee are of opiuion that at present action on the lines of these suggestions would be sufficient. The effect of these should be carefully watched and further measures can be decided on as they seem necessary.

It will be noticed that suggestion No. $I$ is for voluntary, and not compulsory, notification of tuberculosis by medical men.

Suggestion No. 2 will involve expenditure, but the committee think Suggestion No. 2 will involve expenditure, but
it will be very useful and necessary expenditure.

With regard to suggestions Nos. 3,4 , and 5 disinfection and limewashing may, so far as possible, be left to the people themselves, not washing may, so far as possible, be left to the people themselves, not for irritation, but tather than that it should not be done at all it may even be done at municipal expense. A discretion must therefore be given to the health officer to do it at municipal expense and by municipal agency whenever he thinks it necessary.

As to suggestion No. 6, the provision of sanatoria will be more a matter for the munificence of wealthy citizens whose attention should be drawn to the great good whieh institutions of the kind are calculated to do to the suffering poor. The committee hope that the public press, both English and vernacular, will help to keep the matter constantly before the public.

Continuous and persistent action on the lines indicated in the above suggestions will, the committee think, to some extent contribute to check the growing ravages of this disease, which appears to have taken so firm a hold of the many densely crowled sections of this city, such as Second Naopada, Umerkhari, Chakla, Kamatipura, Kharo Talao, Mandvi, and Bhuleshwar. The committee, therefore, beg to recommend that the Commissioner be asked to take the necessary steps for giving effect to these suggestions, submiting proposals to steps for giving effect to these suggestions, submitting proposals to the corporatio

\section{$\begin{array}{ll}\text { H. P. WAMHA. } & \text { BHALCHANDRA KRISHY } \\ \text { K. E. DADACHANII. }\end{array}$ \\ May 9th. N. N. KaTHAK. $\quad$ D. A. D'MONTE.}

\section{The Plague Epidemie throughout India.}

There is again this week a satisfactory decline in the mortality from plague throughout India. The decline is general but in Karachi the disease is raging with great intensity. There were 11,612 deaths in India from plague for the week ending May 10th, as against 15,748 for the previous seven days. For the corresponding week of 1901 there were only 2592 deaths. The chief districts affected are Bombay city with 391 deaths ; Bombay districts, 583 deaths ; Karachi, 122 ; Madras Presidency, 13; Calcutta, 280 ; Bengal districts, 337; United Provinces, 417; the Punjab, 9192 ; Mysore State, 70; and Kashmir, 212. In the two cities of Calcutta and Bombay the outbreaks are now rapidly declining. In neither city, however, has the outbreak attained the same intensity as did those of last year. In Calcutta the outbreak has been much more prolonged. There has been no further development in Eastern Bengal. It is satisfactory to find that the mortality in Bombay apart from plague is coming down to its normal level.

May 15th.

\section{MANCHESTER.}

\section{(FROM OUR OWN CORRESPONDENT.)}

\section{Manchester Royal Infirmary.}

IT appears as if the board of management of the Manchester Royal Infirmary were committed to rebuilding on the present site. At the meeting of the board on May 26th the chairman, Sir J. Forbes Adam, said that it would be remembered with regard to the rebuilding of the infirmary that the plans were passed subject to certain alterations and that they were referred back to be dealt with by the subcommittee. The sub-committee had been working with the architects and the plans, finally changed and with all the suggestions carried out, would be ready on June 17th. The Coronation festivities would cause some delay and it would probably be the third week of July before the trustees' meeting would be held. The trustees will probably be guided by the board as to the decision which they will come to. The plans are not yet made public and they cannot therefore be criticised, but the site is there for anyone to see. It comprises in all 19,580 square yards, or 22 yards more than four acres. On this restricted plot of ground buildings are to be erected giving superficial area and cubic space sufficient to accommodate 457 patients. In addition to the patients there is at the present time a household of more than 140 persons, and when the number of patients is nearly doubled the staff of officers, nurses, and servants must be largely increased, so that probably 700 people will be lodged in the infirmary. This is a high number per acre. The pungent winter fogs cause much suffering and injury to patients with diseases affecting respiration and discomfort to others. A little further from the centre, though there may be fog, it is less charged with acrid, irritating particles and gases. Immediately surrounded as the present wards are with streets and noisy traffic all day and a good part of the night there is no quiet freedom from jarring sounds.

\section{City Electrioal Generating Station.}

A new generating station is in course of construction in Manchester. It is situated in Bradford, one of the industrial suburbs, and the first completed portion was opened by the Lord Mayor on May 27th. The site has an area of $8 \frac{1}{3}$ acres-considerably more than twice that of the infirmary site-and when finished the station will be one of the largest of its kind in the world, providing accommodation for machinery of 70,000 horse power. The cost is expected to be at least $£ 1,000,000$. In accordance therefore, with a law that seems almost to be universal it will probably be half as much again. The first municipal electrical works in Manchester were established in 1893 with machinery for generating 3000 horse power.

\section{Small-pox.}

Many cases of small-pox have recently been notified to the medical officer of health of Derbyshire. A navvy, lately working at Bamford and now living in Chapel-en-le-Frith, has been attacked, and it is feared that he may have communicated the disease to some members of the great colony of navvies now engaged on the preliminary work in connexion with the Derwent Valley Waterworks. In 1893 the authorities had an immense amount of trouble through small-pox spreading among the navvies employed on the Dore and Chinley Railway Works when Chapel-en-le-Frith was the seat of the epidemic. There are said to be 10 cases at Ilkeston, two at Ripley, and several at Chesterfield. Two cases at Derby are traceable to tramps, in regard to whom the authorities just now have to be especially vigilant. Manchester ha 